\title{
Librarian/Faculty Interaction at Nine New England Colleges
}

\section{Donald H. Dilmore}

Faculty members play a central role on college and university campuses, and their perceptions of library service may be a key factor in the way the campus library is used and supported. In an attempt to meet their needs, many librarians are expanding the level of contact they have with their campus constituency. This article presents the results of a study of librarian/faculty interaction at nine small (1,000-4,000 students) college libraries. The study explored several of the activities that librarians employed to build bridges to classroom faculty members, and it also surveyed faculty members' perceptions of library efforts to provide service.

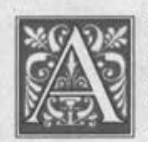

s components of larger institutions, academic libraries face increasing pressures to provide services that will support the instructional and research mission of their parent institutions. It may be assumed by many academic librarians that communication with faculty and other constituencies of the campus community is an effective way for the library to maintain relevance with the program of the college or university. However, research exploring librarian/faculty communication and the possible relationship between that communication and faculty perceptions of library service and use of the library appears to be limited. This communication may be essential for an effective relationship between the library and its environment. As Gerald Zaltman, Robert Duncan, and Jonny Holbek state:

The organization continually must obtain several kinds of information from the environment. First, it must determine the kinds of outputs the environment seeks that may require innovation to be more readily received by the environment. Second, it must discover the kinds of technology or means that may be required to produce the innovationwhat are other organizations doing - are there existing innovations that the organization might adopt to facilitate its response to these needs? Third, once the organization does in fact implement the innovation, is the innovation effective in meeting the demands of the environment? Here it is necessary for the organization to get feedback from the external environment. ${ }^{1}$

Joanne Euster identifies both change and survival as potential products of interaction with the environment, saying, "Adaptation to social and technological

Donald H. Dilmore is Assistant Vice-President for Libraries at Edinboro University of Pennsylvania; e-mail: ddilmore@edinboro.edu. The author wishes to thank Hendrik Edelman of Rutgers University for reviewing drafts of this article. 
change implies an understanding of the environment and the ability to draw resources for organizational change and survival from the environment." 2

This article describes a study that the author conducted in an effort to determine whether interaction was taking place between academic libraries and the faculty and how that interaction was occurring. It also sought to explore possible relationships between librarian/faculty interaction and faculty perceptions ofand use of-library services.

On college campuses, librarians share objectives with the faculty such as providing students with knowledge and skills that will serve them long after graduation, but boundaries between librarians and faculty members exist in the form of differing tasks and outputs. In addition, libraries are often separated spatially from most or all of the faculty.

\section{Literature Review}

Several researchers have explored user needs and opinions of libraries and various library services on campuses. John Budd and Mike DiCarlo investigated user satisfaction at two universities, Mary Sellen and Jon Jirouch conducted a survey contrasting perceived and actual library use by students and faculty, and Susan Hilchey and Jitka Hurych explored user satisfaction or acceptance of online reference services. ${ }^{3-5}$ Other researchers have contributed studies that explore the role of the library in academic institutions. In her study, M. Cathy Cook questioned faculty members at Southern Illinois University to obtain their perceptions of librarians' status and the quality of service. She attempted to determine whether librarians were maintaining a presence outside the library by asking faculty members whether they had contact with librarians in nonlibrary settings. ${ }^{6}$ Larry Hardesty worked toward developing a scale based on responses to fifteen positive and fifteen negative statements that measured the attitude of undergraduate classroom instructors toward the role of the academic library in the instructional program. ${ }^{7}$ Research on this topic has continued into this decade. In his 1990 study of faculty members at Memphis State University, Robert Ivey used twenty-three

\section{FIGURE 1 \\ Questions Asked to Obtain Outreach Data}

1) How are librarians involved in outreach activity?

A) What types of outreach activities are employed by librarians?

B) Do librarians' perceptions of their outreach activities correlate with their faculty colleagues' perceptions of their activities? Which of these activities do faculty members regard as important?

C) Do library directors tend to be the sole or principal outreach agents among librarians?

D) Is outreach between librarians and faculty members seen by librarians as an important cause of change in the library?

2) Is there a relationship between the outreach activity of librarians and the perception of and use of library services by faculty members? Is the role of outreach activity as important in shaping perceptions and use as:
A) departmental affiliation?
B) number of years at that institution?
C) distance to another library with a strong collection in the faculty members' areas of interest?
D) other factors? 
questions to study faculty members' perceptions of the value of library services at that institution. ${ }^{8}$

Few researchers have explored the extent to which librarians attempt to maintain an awareness of their campus environment. Those researchers who studied the role of communication in libraries usually investigated communication that takes place within the library, and those who studied the problem of external communication frequently focused on the advertising of services and other public relations issues. Although the need to consider the environment was raised by researchers such as Beverly Lynch and Dennis Carrigan, little research exists on the efforts of librarians to establish and maintain contact with the communities they serve in order to anticipate and respond to changing needs.., 10

Except for a study designed by Larry Oberg, Mary Kay Schleiter, and Michael Van Houten to relate interaction between faculty members and the library to the status of the librarians and the perceived importance of the library in the campus program at Albion College, few explorations of this relationship exist. ${ }^{11}$ However, several researchers have investigated the relationship between the academic library director and the rest of the campus. Although a study by Susan Lee concluded that directors devote much of their time to campus matters that are external to the library, other studies by Paul Metz, Michael Moskowitz, and Terrence Mech indicated that library directors spend most of their time on internal library matters. ${ }^{12-15}$ However, Mech found that responses differed between the types of institutions, with directors of baccalaureate and community college libraries spending more time with faculty and students than did directors of other types of academic libraries. ${ }^{16}$

When the library is called upon to participate in college or university committees, it is often the director who is asked to serve as the representative of the li- brary. However, this activity should not be the responsibility of the director only. As Marshall Meyer states, "Organizations that are rational, and hence responsive to environmental uncertainties, require considerable boundary-spanning activity, only part of which can be handled by a single leader:"17

In exploring the concept of outreach as it relates to the provision of library service in academic institutions, the author asked two main questions and a number of subsidiary questions (see figure 1 ). $\mathrm{He}$ chose faculty members for inclusion in this study because of the central role they play on campus. Many writers have mentioned the importance of faculty/librarian interaction, including Allen Veaner, who stated: "No matter how strong an image a president or chancellor projects, the faculty is the prime focus of political power in every school.... They are without question the most formidable force on campus." 18

\section{Methodology}

To address the questions in figure 1 , the author examined the amount of outreach activity taking place between librarians and faculty members by asking librarians to maintain a log of the faculty members whom they contacted during the course of two workweeks. He mailed ten copies of activity logs to each librarian at the colleges participating in the study. These logs contained lists of faculty members employed by the college. Each librarian checked the list each time he or she had contact with a faculty member. The use of these forms was based on the work of Thomas Allen in his network studies of research laboratory personnel. ${ }^{19}$ The author used the records gathered in this study to determine the number of faculty members contacted by each librarian and to calculate the percentage of faculty members contacted for each campus.

Along with the activity logs that the librarians compiled, the author mailed questionnaires to all of the professional 
librarians and to a sample that included between fifty and sixty-five faculty members at each of the nine participating colleges. Several of the questions were based on those developed by Joanne Euster in her study of library administrators and on the work of John Budd, Mike DiCarlo, David Kaser, and Jinnie Davis..$^{20-22}$ These questions were pretested at a college that did not participate in the study.

Although the author sent librarians and faculty members different questionnaires, both groups received several of the same questions concerning the extent of librarian outreach. The author compared results for the two groups to determine how well the librarians' perceptions of their outreach efforts matched their faculty colleagues' perceptions. As another measure of outreach activity, faculty members also were asked how long it had been since they had last spoken with a librarian.

The author supplemented information obtained from the mail survey with group discussions he held with the librarians and faculty members of the colleges taking part in the study. The faculty members interviewed were among those who responded to the mail survey.

The author contacted directors of thirty New England college libraries by letter to request their cooperation in the project. The colleges had enrollments of 1,000 to 4,000 students and offered programs that focused on undergraduate studies. The author used a limited range of institutional types to reduce variations in faculty use and attitudes that may exist as a result of widely differing campus characteristics. After the initial mailing and follow-up phone calls to nonresponding librarians, the library directors of nine colleges agreed to participate in the study.

\section{Survey}

The author sent forms to 511 faculty members from a total faculty population of 1,397 at the nine colleges. Participants answered and returned a total of 239 surveys. One follow-up mailing of reminder notices to nonresponding faculty members resulted in few additional replies. The response rate was approximately 47 percent. The response rate for the individual campuses ranged from 34 to 63 percent.

The librarians' activity logs reported contacts with a total of 599 faculty members, 43 percent of the 1,397 faculty members listed on the rosters. Of these, 116 were faculty members who had responded to the survey. Librarians reported no conversations with the other 123 faculty respondents. On the basis of these numbers, 49 percent of the faculty members responding to the survey were contacted by librarians during their twoweek reporting periods.

A total of fifty questionnaires were returned by the fifty-nine librarians who received them, for a response rate of 85

The only two areas that a majority of the respondents considered to be important were those that are most directly associated with the actual delivery of library service.

percent. The response rate of the librarians from eight of the colleges was 100 percent, while the response rate from one institution was 47 percent. Questions asked at the interview revealed that many of the nonrespondents were part-time or temporary employees.

\section{Interviews}

The author visited all nine participating campuses to interview the librarians and groups of faculty members. He used the interviews to gather additional information to supplement the information already obtained through the questionnaires. On each campus, he held one interview session for librarians and a separate session for faculty members. Faculty members who indicated an interest in at- 
tending the interviews received reminders of the meetings. Although several faculty members on each campus expressed an interest in the sessions, only one or two met for the interview on six of the nine campuses. Attendance was higher at the other three colleges. Although attendance was disappointing, the author gathered additional insights from the interviews. The proportion of librarians who attended, however, was much higher. In fact, at several colleges, all of the professional librarians attended. The author took notes at all of the sessions and taperecorded them for later reference.

\section{Data Analysis}

The author used nonparametric analysis to study the data because the data were usually either ordinal or nominal, and the interval level data he collected were usually skewed to the point where logarithmic transformation did not reduce the skewness to less than 0.5 , a level called for in parametric analysis. The SPSS-X statistical package was used for the analysis.

Evidence obtained through the interviews indicated that the nine libraries taking part in the study participated in a range of activities that kept them in contact with the campus community. Table 1 presents a summary of these activities.

\section{Rankings}

In compiling rankings from the survey responses, the author found that the librarians consistently gave themselves lower scores than faculty members gave them for several outreach activities. As table 2 illustrates, results from the Mann-Whitney $U$ test indicate that differences between the responses of librarians and of faculty members were significant $(\mathrm{p}<.05)$ for the entire sample. However, they were rarely significant at the campus level. The author used KolmogorovSmirnov two-sample tests to analyze campus-level results because the sample sizes on the individual campuses were small. (Copies of questionnaires are available from the author.)

Faculty members on all nine campuses generally gave low marks to the importance of the outreach activities listed on the survey. The only two areas that a majority of the respondents considered to be important were those that are most directly associated with the actual delivery of library service. These areas were: 


\begin{tabular}{|c|c|c|c|c|c|}
\hline \multirow[b]{3}{*}{ Activity } & \multicolumn{4}{|c|}{$\begin{array}{l}\text { TABLE } 2 \\
\text { orarians' Outreach Activity } \\
\text { Ity and Librarians' Responses }\end{array}$} & \\
\hline & \multicolumn{2}{|c|}{ Faculty } & \multicolumn{2}{|c|}{ Librarians } & \\
\hline & $\mathrm{N}$ & Response & $\mathrm{N}$ & Response & \\
\hline Service as experts & 227 & 3.85 & 47 & 3.57 & \\
\hline Keep others informed & 231 & 3.49 & 46 & $3.02 *$ & \\
\hline $\begin{array}{l}\text { Attend social } \\
\text { functions }\end{array}$ & 204 & 3.32 & 47 & $2.81 *$ & \\
\hline Serve on committees & 204 & 3.60 & 47 & $2.85^{*}$ & \\
\hline $\begin{array}{l}\text { Stay attuned to } \\
\text { communication ntwks. }\end{array}$ & 189 & 3.62 & 46 & $3.20 *$ & \\
\hline $\begin{array}{l}\text { Knowledgeable about } \\
\text { campus activities }\end{array}$ & 199 & 3.68 & 47 & $3.13^{*}$ & . \\
\hline $\begin{array}{l}\text { Provide library } \\
\text { instruction }\end{array}$ & 224 & 4.04 & 47 & $3.02 *$ & \\
\hline
\end{tabular}

serving as experts by providing advice to students and faculty about how to use information resources and by providing formal instruction in the use of the library.

Although faculty members gave low scores to the importance of several library outreach activities, they gave rather high scores to a few. This section seeks to explore whether the outreach activity of librarians is a factor in faculty perceptions of the quality of library service and in their use of the library.

\section{Correlations}

The author used Spearman rank correlation analysis to investigate the relationship between several variables involved in this study because the data were skewed. The variables selected for analysis were:

- walktime, the number of minutes that it takes faculty members to walk from their offices to the library at their college;

- talklib, the number of days since the faculty member last spoke with a librarian from his or her college;

- locuse, the number of times the faculty member uses the campus library, on average, during the course of a semester;

- otheruse, the number of times during a semester that a faculty member uses, on average, another library for study or research;

- mileslib, the number of miles to another library with a collection that is strong in the faculty member's subject area;

- $s v c$, the faculty member's perception of the quality of service provided by the library at his or her college;

- years, the number of years the faculty member has served at that college.

Many of these variables are similar to those used in other studies of library use and faculty perceptions of librarians. In this analysis, the author quantified outreach activity as the number of days since a faculty member had spoken with a librarian (see table 3).

According to the analysis presented in table 3 , there is a significant correlation $\left(\mathrm{r}_{\mathrm{s}}=.38, \mathrm{r}_{\mathrm{s}}^{2}=.15, \mathrm{p}<.05\right)$ between the number of times members had spoken with librarians as reported on the faculty survey forms and their perception of library service as reported on a scale of 1 to 5 , with 1 indicating poor service; 2 , fair service; 3 , adequate service; 4 , good service; and 5 , excellent library service. The correlation indicates that researchers may reject the null hypothesis that there is no 
difference in the perceptions of library service related to the length of time between librarian/faculty interaction. The negative correlation indicates that longer periods of time between contacts with librarians correlate with less favorable perceptions of library service. These findings complement those of the Oberg, Schleiter, and Van Houten study in which they stated: "Our data demonstrate that the greater the faculty contact with the library, the higher the rank given the librarians." 23 These findings also reflect those of Ivey, in which faculty members who are frequent users of the library referred students to a librarian significantly more often than did infrequent users. Ivey surmises, "It may be that frequent users have more confidence in librarians' abilities than do infrequent users, who may be more apathetic about library services and librarians." 24

To explore these findings, the author divided faculty members into two groups: those who were checked on the librarians' activity logs as having been contacted, and those with whom the librarians reported no conversations. For the 115 respondents who were contacted during the ten-day record-keeping periods, the median score given for library service was 5 ("excellent"). The median score given

\begin{tabular}{|lcc|}
\hline \multicolumn{3}{|c|}{ TABLE 3 } \\
Summary of the 10 Largest Spearman \\
Rank Correlations \\
\hline \hline Variables & $\mathrm{r}_{\mathrm{s}}$ & $\mathrm{r}_{\mathrm{s}}{ }^{2}$ \\
\hline SVC \& COLLECTN & $.44^{*}$ & .19 \\
SVC \& TALKLIB & $-.38^{*}$ & .14 \\
LOCUSE \& TALKLIB & $-.35^{*}$ & .12 \\
YRS \& COLLECTN & $.34 *$ & .11 \\
SVC \& YRS & $.29 *$ & .08 \\
OTHERUSE \& COLLECTN & $-.27 *$ & .07 \\
SVC \& LOCUSE & $.26 *$ & .07 \\
NUMLIBN \& MILESLIB & $-.24 *$ & .05 \\
NUMLIBN \& LOCUSE & $.23 *$ & .05 \\
NUMLIBN \& COLLECTN & $.23 *$ & .05 \\
\hline *Significant (p<.05) & & \\
\hline
\end{tabular}

by the 122 whom librarians did not contact was 4 ("good"). The Mann-Whitney $\mathrm{U}$ test, which compared the responses from the two groups, indicated that the differences were significant $(p<.05)$. From a total of 239 usable questionnaires returned by faculty members, there were 232 responses to the question, "Approximately how many times, on average, during a semester do you use the library on your campus either by a personal visit or through an assistant?" There was a negative Spearman correlation $\left(r_{\mathrm{s}}=-.35, \mathrm{r}_{\mathrm{s}}^{2}=\right.$ $.13, \mathrm{p}<.05$ ) between the time faculty members last spoke with a librarian and the number of times they reported using the library on their campus during the course of a semester. The negative correlation indicates that a lengthier period of time since a faculty member has spoken with a librarian correlates with a lower frequency of library use. This supports the findings of the Oberg, Schleiter, and Van Houten study which found that, "Not surprisingly, frequent library users report a higher frequency of contact with librarians in a library setting than do infrequent users." 25 Although the author developed the measure in this study with an interest in communication outside the library setting as well as within it, the findings appear to be complementary.

The mode for the faculty response is twenty visits to the library per semester, the mean is eighteen visits $(\mathrm{SD}=17)$, and the median response was fifteen. Nine of the faculty members responded with zero times per semester. For the 113 responding faculty members contacted by librarians, the median response was eighteen times per semester, the mode response was twenty, and the mean number of times reported was twenty-four. For the 118 responding faculty members not contacted, the median response was ten times, the mode response was ten, and the mean of the responses was thirteen times per semester. With $\mathrm{N}=231$, the dif- 
ference between the two groups as indicated by the Mann-Whitney U test is significant $(\mathrm{p}<.05)$.

This raises a question that cannot be answered by the data collected for this study. To what extent does the correlation between faculty perceptions of the quality of library service and the length of time since faculty members spoke with a librarian occur as a result of increased familiarity with the librarian and not necessarily from responsive service?

With evidence indicating a statistically significant correlation between librarian/ faculty contact and faculty use and perceptions of the quality of library service, the author decided to study other factors to determine whether they, too, are correlated $(\mathrm{p}<.05)$. He tested departmental affiliation for correlation with faculty perceptions of library service and use of the library. For these tests he divided faculty members into four subject area groups: professional studies, liberal arts, science, and social sciences. When the author ran a Mann-Whitney U test between the subject pairings, $N=237$, he found no significant differences $(p<.05)$ in perceptions of the quality of library service provided. However, there were significant differences in the use reported by the four groups. According to their reports, liberal arts faculty members used the library at a frequency that was significantly higher $(\mathrm{p}<.05)$ than that for either professional studies faculty or science faculty members. Social sciences faculty members also used the library at a frequency that was significantly higher than the frequency for science faculty members.

Another factor analyzed was length of faculty service at the colleges being studied. Using SPSS-X to run a Spearman rank correlation, the author found a positive correlation between the number of years a faculty member served at a college and his or her perception of library service at that institution. With $\mathrm{N}=234$, the Spearman correlation $\left(\mathrm{r}_{\mathrm{s}}=.29, \mathrm{r}_{\mathrm{s}}^{2}=.08\right)$ was significant $(\mathrm{p}<.05)$, suggesting that a lengthier tenure at an institution correlates with a more positive view of library service. This supports a finding by Jinnie Davis and Stella Bentley that, "Faculty members with less time at an institution are the most dissatisfied members." ${ }^{26}$

Spearman rank correlation also indicated that there was a significant positive correlation between the number of years a faculty member served at the college and the number of times he or she reported using the campus library during the course of a semester. Using $\mathrm{N}=231$, the Spearman correlation for this pair of

The negative correlation indicates that a lengthier period of time since a faculty member has spoken with a librarian correlates with a lower frequency of library use.

variables was weak but significant $\left(\mathrm{r}_{\mathrm{s}}=\right.$ $\left..11, \mathrm{r}_{\mathrm{s}}^{2}=.01, \mathrm{p}<.05\right)$. This finding contradicts the speculation in the Davis-Bentley study that newer faculty members may use the library more frequently. ${ }^{27}$

Distance from the faculty members' offices to the campus library was another factor studied. The author determined distance by asking faculty members how many minutes it took to walk from their office to the library. Studies such as those by James Miller and by T. J. Allen and A. R. Fusfeld indicate a correlation between propinquity and communication behavior. ${ }^{28,29}$ However, with $\mathrm{N}=235$ and a Spearman correlation of -.07 , there is only a weak correlation between the distances from faculty members' offices to the libraries and their perceptions of library service. In addition, the Spearman rank correlation test indicates no significant difference $(\mathrm{p}<.05)$ between the distance to the campus library and the number of times faculty members use the library during the course of a semester.

The fact that this study includes only small colleges may be a factor in evaluating the importance of the distance vari- 
able. From more than 230 responses, only eighteen faculty members reported that it took longer than five minutes to reach the library from their offices, and only four reported times of more than ten minutes.

Spearman rank correlation indicates a weak but significant negative correlation $\left(\mathrm{r}_{\mathrm{s}}=-.15, \mathrm{r}_{\mathrm{s}}^{2}=.02, \mathrm{p}<.05\right)$ between the distance to a library with a strong collection in the faculty member's area of interest and the faculty member's perception of the quality of library service on his or her campus. With $\mathrm{N}=217$ and a

\section{The area where faculty involvement appeared to have the most impact was in bibliographic instruction.}

Spearman correlation of .06 , there is a weak positive correlation indicating some relationship in this sample between more frequent use of the campus library and an increasing distance to another library with strength in the faculty member's area of interest. However, that correlation is not significant $(\mathrm{p}<.05)$.

The author also studied other factors to explore their relationships with faculty perceptions and use of library services. As shown in table 3, faculty perceptions of the quality of the library collection play an important role in their perceptions and use of library services. With $\mathrm{N}=235$, the Spearman rank correlation between perceptions of the quality of the collection and perceptions of the quality of library service $\left(r_{s}=.44, r_{s}^{2}=.19, p<.05\right)$ was the highest among the pairs of variables studied. The correlation between faculty members' perceptions of the quality of the collection and their use of the library was not as strong $\left(\mathrm{r}_{\mathrm{s}}=.22, \mathrm{r}_{\mathrm{s}}^{2}=.05\right)$, but was significant $(\mathrm{p}<.05)$. The author also found significant correlations $(p<.05)$ between the size of the professional library staff and faculty perceptions and use of library services. However, these correlations are not as strong as those combining faculty use and perceptions of library service with collection quality and the number of days since faculty members had spoken with librarians.

The author asked librarians to name three new ideas that had been implemented during the year prior to the survey and to tell how they introduced those ideas to the library. He asked this question to determine whether any new ideas had been introduced to the library through interaction with faculty members. Jose Marie Griffiths noted that innovation could be brought to the library by its users. However, in this study, the spread of innovation to libraries by library users did not appear to be the norm expected by those interviewed..$^{30}$ According to the responses, the library received few if any ideas for innovation in library service from the faculty, but faculty support was, in some instances, seen as a key element in implementing innovation or improvements. The area where faculty involvement appeared to have the most impact was in bibliographic instruction. At one of the colleges, a librarian and a faculty member developed a workshop that focused on the need for increased faculty/librarian cooperation in bibliographic instruction and class assignments. At the two colleges where most of the faculty ratings placed the libraries near the top in quality of service provided and in boundary-spanning activity, interviews also revealed that the librarians took an active role in interaction with the faculty and students.

\section{Conclusion}

The interaction between librarians and classroom faculty members was a crucial element of this study. Interaction consisted of a range of forms and involved, in part, the delivery of services and exchange of information.

As shown in table 3 , the measure of interpersonal contact was one of the strongest predictors of faculty perceptions and use of library services in this study. Information gathered through the inter- 
views supported this relationship. Although the author explored several other factors, only faculty perceptions of the quality of the library collection exceeded interpersonal contact as they correlated with faculty perceptions of the quality of library service. One of the most interesting results of the survey was the finding that one of the smallest libraries to participate in the study recorded one of the most active programs of outreach and received among the highest marks for faculty perceptions of service.

A question not answered in this study is how increased interpersonal contact relates to higher faculty perceptions and use of library services. Were the exchanges that took place between librarians and faculty members mainly ones of affect, or friendship, or did the exchanges involve the transfer of information or other resources that led to actual improvements in service? Furthermore, several types of exchanges took place in the libraries studied, but the author was unable to determine the degree to which any particular type of exchange occurred from the data gathered for the purposes of this study. However, of the campuses studied, those where library service appeared to be most valued by the faculty were those on which librarians reported the most frequent interaction with faculty members. Thomas Allen explains a possible cause of this phenomenon in his study of research and development laboratory personnel. In the following passage, he finds that social contact can benefit the organization:

When two people are acquainted, they are also able to communicate more effectively. The understanding that develops between engineers through their social and work contacts is therefore important not only in encouraging communication but also in increasing its effectiveness. If one individual is familiar with another's background, he is better able to tailor his responses to the other's abilities. ${ }^{31}$

The author also found that of the outreach activities studied, the activities that faculty respondents thought were most important involved the direct provision of service. Faculty members gave activities such as service on campuswide committees much lower scores.

\section{Notes}

1. Gerald Zaltman, Robert Duncan, and Jonny Holbek, Innovations and Organizations (New York: Wiley, 1993), 120-21.

2. Joanne Euster, The Academic Library Director: Management Activities and Effectiveness (New York: Greenwood Pr., 1987), 4.

3. John Budd and Mike DiCarlo, "Measures of User Evaluation at Two Academic Libraries: Prolegomena," Library Research 4 (spring 1982): 71-84.

4. Mary K. Sellen and Jon Jirouch, "Perceptions of Library Use by Faculty and Students: A Comparison," College \& Research Libraries 45 (July 1985): 259-67.

5. Susan Hilchey and Jitka M. Hurych, "User Satisfaction or User Acceptance? Statistical Evaluation of On-line Reference Service," $R Q 24$, no. 4 (summer 1985): 452-59.

6. M. Cathy Cook, "Rank, Status, and Contribution of Academic Librarians As Perceived by the Teaching Faculty at Southern Illinois University, Carbondale," College \& Research Libraries 42 (May 1981): 214-23.

7. Larry L. Hardesty, "The Influence of Selected Variables on Attitudes of Classroom Instructors toward the Undergraduate Educational Role of the Academic Library," in Academic Libraries: Myths and Realities, Proceedings of the Third National Conference of College and Research Libraries, eds. Suzanne C. Dobson and Gary L. Menges (Chicago: ACRL, 1984), 365-77.

8. Robert T. Ivey, "Teaching Faculty Perceptions of Academic Librarians at Memphis State University," College \& Research Libraries 55 (Jan. 1994): 69-82. 
9. Beverly P. Lynch, "The Academic Library and Its Environment," College \& Research Libraries 35 (Mar. 1974): 126-32.

10. Dennis P. Carrigan, "The Political Economy of the Academic Library," College \& Research Libraries 49 (July 1988): 325-31.

11. Larry R. Oberg, Mary Kay Schleiter, and Michael Van Houten, "Faculty Perceptions of Librarians at Albion College: Status, Role, Contribution, and Contacts," College \& Research Libraries 50 (Mar. 1989): 215-30.

12. Susan Lee, "Conflict and Ambiguity in the Role of the Academic Library Director," College \& Research Libraries 38 (Sept. 1977): 396-403.

13. Paul Metz, "The Role of the Academic Library Director," Journal of Academic Librarianship 5, no. 3 (July 1979): $148-52$.

14. Michael A. Moskowitz, "The Managerial Roles of Academic Library Directors: The Mintzberg Model," College \& Research Libraries 47 (Sept. 1986): 452-59.

15. Terrence Mech, "Academic Library Directors: A Managerial Role Profile," College \& Research Libraries 51 (Sept. 1990): 415-28.

16. Ibid.

17. Marshall Meyer and Associates, Environments and Organizations (San Francisco: JosseyBass, 1978), 204.

18. Allen B. Veaner, Academic Librarianship in a Transformational Age: Program, Politics, and Personnel (Boston: G. K. Hall, 1990), 209.

19. Thomas J. Allen, Managing the Flow of Technology: Technology Transfer and the Dissemination of Technological Information within the R \& D Organization (Cambridge, Mass.: Massachusetts Institute of Technology, 1977), 300-06.

20. Euster, The Academic Library Director, 70-75.

21. Budd and DiCarlo, "Measures of User Evaluation at Two Academic Libraries," 71-84.

22. David Kaser and Jinnie Y. Davis, The Viability of Merging Three Academic Libraries in Worcester (Bloomington: Indiana University Graduate Library School, 1977), 93-98.

23. Oberg, Schleiter, and Van Houten, "Faculty Perceptions," 225.

24. Ivey, "Teaching Faculty Perceptions," 75.

25. Oberg, Schleiter, and Van Houten, "Faculty Perceptions," 218.

26. Jinnie Y. Davis and Stella Bentley, "Factors Affecting Faculty Perceptions of Academic Libraries," College \& Research Libraries 40 (Nov. 1979): 527-32.

27. Ibid.

28. James G. Miller, "Living Systems: Basic Concepts," Behavioral Science 10, no. 3 (July 1965): 193-237.

29. Thomas J. Allen and A. R. Fusfeld, "Research Laboratory Architecture and the Structuring of Communications," $R$ \& D Management 5, no. 2 (1975): 153-64.

30. Jose Marie Griffiths, R. G. Havelock, and E. A. Sweet, Diffusion of Innovations in Library and Information Science, final report (Rockville, Md.: King Research, 1986), 4. ERIC document: ED 279350.

31. Allen, Managing the Flow of Technology, 198.

\section{IN FORTHCOMING ISSUES OF COLLEGE \& RESEARCH LIBRARIES}

The Development of a Lower Division General Education CourseIntegrated Literacy Program-Gabriela Sonntag and Donna M. Ohr

Collections at Risk: Revisiting Serial Cancellations in Academic Libraries-Tina E. Chrzastowski and Karen A. Schmidt

Authorship in College \& Research Libraries Revisited-James L. Terry Data-Guided Collection Development-Dennis P. Carrigan 